\title{
Efficient ceria-silica catalysts for BTX oxidation: Probing the catalytic performance and oxygen storage
}

\author{
Anderson G.M. da Silva ${ }^{a}$, Humberto V. Fajardo ${ }^{b}$, Rosana Balzer ${ }^{c}$, Luiz F.D. Probst ${ }^{c}$, Nayara T. Prado ${ }^{\mathrm{d}}$, \\ Pedro H.C. Camargo ${ }^{a}$, Patricia A. Robles-Dutenhefner ${ }^{\mathrm{d}, *}$ \\ a Departamento de Química Fundamental, Instituto de Química, Universidade de São Paulo, Av. Prof. Lineu Prestes, 748, 05508-000 São Paulo, SP, Brazil \\ ${ }^{\mathrm{b}}$ Departamento de Química, Universidade Federal de Ouro Preto, 35400-000 Ouro Preto, MG, Brazil \\ ${ }^{\mathrm{c}}$ Departamento de Química, Universidade Federal de Santa Catarina, 88040-900 Florianópolis, SC, Brazil \\ ${ }^{\mathrm{d}}$ Departamento de Química, Universidade Federal de Minas Gerais, 31270-901 Belo Horizonte, MG, Brazil
}

\section{H I G H L I G H T S}

- $\mathrm{CeO}_{2}$ based catalysts were prepared by impregnation method and MCM-41 supports.

- The method of preparation affects the dispersion/incorporation of the $\mathrm{CeO}_{2}$ which led to higher catalytic activities.

- $\mathrm{CeO}_{2}-\mathrm{MCM}-41$ material showed better BTX oxidation capacity.

\section{A R T I C L E I N F O}

\section{Article history:}

Received 30 July 2015

Received in revised form 27 October 2015

Accepted 30 October 2015

Available online 4 November 2015

\section{Keywords:}

BTX oxidation

Ceria-silica catalyst

MCM-41

\begin{abstract}
A B S T R A C T
This paper describes a systematic investigation on the synthesis of $\mathrm{CeO}_{2}$ supported on $\mathrm{SiO}_{2}$ by two different methods: (i) the in situ incorporation of $\mathrm{CeO}_{2}$ onto $\mathrm{MCM}-41$ and (ii) wet impregnation. We were interested in investigating how the $\mathrm{CeO}_{2}$ preparation could influence their physicochemical properties and catalytic performances towards the benzene, toluene, and $o$-xylene (BTX) oxidation reactions. Our results showed that the catalytic performances were strongly dependent on the synthetic approach, in which the $\mathrm{CeO}_{2}-\mathrm{MCM}-41$ material prepared by the in situ incorporation showed better BTX oxidation activities than the $\mathrm{CeO}_{2}$-based catalysts prepared by conventional wet impregnation. This result could be assigned to the higher specific surface area, better interaction between $\mathrm{CeO}_{2}$ and the support, improved $\mathrm{Ce}^{4+} / \mathrm{Ce}^{3+}$ redox process, and higher concentration of oxygen vacancies as enabled by the in situ approach. The influence of $\mathrm{CeO}_{2}$ content in the ordering of the $\mathrm{SiO}_{2}$ mesoporous structure was also demonstrated.
\end{abstract}

(c) 2015 Elsevier B.V. All rights reserved.

\section{Introduction}

Ceria $\left(\mathrm{CeO}_{2}\right)$ is widely employed as heterogeneous catalysts towards a variety of reactions due to its interesting properties such as good oxidation-reduction potential, high oxygen storage capability (OSC), and controlled porosities [1-5]. These features play an important role in the context of $\mathrm{CeO}_{2}$-catalyzed oxidation reactions, and originate from the easy formation and mobility of oxygen vacancies, mainly at the surface [6-9].

Especially, $\mathrm{CeO}_{2}$ oxygen vacancies provide sites for oxygen activation and increase the diffusion rate of oxygen, that can be used to enhance catalytic processes [6,8-10]. In order to enhance the number of oxygen vacancies, many strategies have been employed such

\footnotetext{
* Corresponding author.

E-mail address: pard@ufmg.br (P.A. Robles-Dutenhefner).
}

as the inclusion of secondary metal dopants, defects in the structure, and metal-support interactions [10-12]. One of the efficient strategies to provide higher concentration of oxygen vacancies in the $\mathrm{CeO}_{2}$ structure is by metal-support interactions that occur by anchoring $\mathrm{CeO}_{2}$ over a metal oxide $\left(\mathrm{SiO}_{2}, \mathrm{Al}_{2} \mathrm{O}_{3}, \mathrm{ZnO}\right.$, and others) by impregnation, hydrothermal, sol-gel process, electrodeposition and metal precursor hydrolysis [8,13-20].

In this paper, we describe a simple approach for the synthesis of $\mathrm{CeO}_{2}$ supported on $\mathrm{SiO}_{2}$ catalysts obtained by two different methods: (i) $\mathrm{CeO}_{2}-\mathrm{MCM}-41$ obtained by the in situ incorporation of a cerium precursor into the mesoporous silica MCM-41 framework, and (ii) $\mathrm{CeO}_{2}-\mathrm{SiO}_{2}$ obtained by conventional wet impregnation of commercial $\mathrm{CeO}_{2}$ over $\mathrm{SiO}_{2}$ and $\mathrm{Ce}\left(\mathrm{NO}_{3}\right)_{3}$ over $\mathrm{MCM}-41$. It is important to note that, in the $\mathrm{CeO}_{2}$ containing MCM-41, the active site-isolation in the framework positions of solid matrices prevents metal aggregation to produce less reactive species [21]. Specifi- 
cally, we were interested in studying how the preparation method of the $\mathrm{CeO}_{2}$-based catalysts could influence their active sitesupport interaction, the concentration of oxygen vacancies, and their corresponding catalytic performances towards benzene, toluene, and $o$-xylene (BTX) oxidation. Although these organic compounds are harmful to the atmosphere and human health, they are still released to the environment by a variety of daily activities. Thus, the BTX oxidation was chosen as a model to probe catalytic performances as it represents one of the most important methods to their removal from the environment due to its high degradation efficiency and low energy costs [22-24].

\section{Experimental}

\subsection{Chemicals}

All reagents were purchased from commercial sources and used as received.

\subsection{Preparation of $\mathrm{CeO}_{2}-\mathrm{MCM}-41$ catalyst by the in situ incorporation of $\mathrm{Ce}$}

$\mathrm{CeO}_{2}-\mathrm{MCM}-41$ (1.0, 5.0 and $\left.10 \mathrm{wt} \%\right)$ catalyst was prepared by the in situ incorporation of Ce into the MCM-41 framework. Tetraethyl orthosilicate (TEOS, 99\%, Sigma-Aldrich), and $\mathrm{Ce}\left(\mathrm{NO}_{3}\right)_{3} \cdot 6 \mathrm{H}_{2} \mathrm{O}$ (99\%, Sigma-Aldrich) were the precursors and hexadecyltrimethylammonium bromide (CTAB, Sigma-Aldrich) was the structural template. A solution of CTAB in water $(4 \mathrm{~g} / 25 \mathrm{~mL})$ was added to a solution of TEOS ( $2.5 \mathrm{~g})$ in aqueous tetramethylammonium hydroxide (TMAOH, $25 \mathrm{wt} \%$, Sigma-Aldrich), and the mixture was stirred for $30 \mathrm{~min}$. Next, $\left(\mathrm{CeNO}_{3}\right)_{3} \cdot 6 \mathrm{H}_{2} \mathrm{O}(0.47 \mathrm{~g}, 2.4 \mathrm{~g}$, and $4.7 \mathrm{~g}$ for 1.0 , 5.0. and $10 \mathrm{wt} \%$ catalysts, respectively), and the remaining TEOS $(21.0 \mathrm{~g})$ were added. After additional stirring at $40^{\circ} \mathrm{C}$ for $24 \mathrm{~h}$, the mixture was autoclaved at $100{ }^{\circ} \mathrm{C}$ for $24 \mathrm{~h}$ and then cooled to room temperature. The resulting solid was separated by filtration, washed with deionized water and ethanol and dried at $40^{\circ} \mathrm{C}$. The solid was then heated from room temperature to $550{ }^{\circ} \mathrm{C}$ under flowing nitrogen and calcined for $3 \mathrm{~h}$ at $550{ }^{\circ} \mathrm{C}$ under a flow of air to remove the residual organic compounds. The TEOS/C16-TAB/ TMAOH/water molar ratio was 1.0/0.12/0.3/22.0.

\subsection{Preparation of $\mathrm{CeO}_{2}-\mathrm{MCM}-41$ obtained by the impregnation of $\mathrm{Ce}$ $\left(\mathrm{NO}_{3}\right)_{3} \cdot 6 \mathrm{H}_{2} \mathrm{O}$ over $\mathrm{MCM}-41$}

Briefly, $126 \mathrm{mg}$ of $\mathrm{Ce}\left(\mathrm{NO}_{3}\right)_{3} \cdot 6 \mathrm{H}_{2} \mathrm{O}$ was dissolved in $30 \mathrm{~mL}$ of deionized $\mathrm{H}_{2} \mathrm{O}$. Then, $1.0 \mathrm{~g}$ of pure MCM- 41 (obtained by the same protocol above mentioned without the use of $\left.\mathrm{Ce}\left(\mathrm{NO}_{3}\right)_{3} \cdot 6 \mathrm{H}_{2} \mathrm{O}\right)$ was added to the resulting suspension and vigorously stirred at $80^{\circ} \mathrm{C}$ to produce a paste. After that, $50 \mathrm{~mL}$ of deionized water was added and the suspension was stirred until completely dry $(\sim 5 \mathrm{~h})$. The resulting solids were then treated at $550{ }^{\circ} \mathrm{C}$ for $3 \mathrm{~h}$ under air.

\subsection{Preparation of $\mathrm{CeO}_{2}-\mathrm{SiO}_{2}$ catalyst by wet impregnation}

$\mathrm{CeO}_{2}-\mathrm{SiO}_{2}$ catalyst was prepared by wet impregnation method. $50 \mathrm{mg}$ of $\mathrm{CeO}_{2}$ (Riedel-de Haen) were suspended in $30 \mathrm{~mL}$ of water. Then, $1 \mathrm{~g}$ of $\mathrm{SiO}_{2}$ (70-230 mesh, VETEC) was added to resulting suspension and vigorously stirred at $80^{\circ} \mathrm{C}$ until the formation of a paste. Then, $50 \mathrm{~mL}$ of distilled water was added and the suspension was kept under stirring to dryness ( $\sim 5 \mathrm{~h}$ ). The resulting solid were then treated at $120^{\circ} \mathrm{C}$ for $2 \mathrm{~h}$ under air. The solid was then heated from room temperature to $550{ }^{\circ} \mathrm{C}$ under a flow of air.

\subsection{Catalyst characterization}

The catalysts were characterized physically and chemically after calcination.

Powder X-ray diffraction (XRD) patterns were recorded on a Rigaku Geigerflex-3034 diffractometer with $\mathrm{CuK} \alpha$ radiation

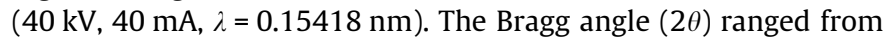
$15^{\circ}$ to $70^{\circ}$, with a step size of $0.05^{\circ}$, and a step time of $4.0 \mathrm{~s}$. Samples were previously dried at $110^{\circ} \mathrm{C}$ overnight and pulverized.

The reducibility of the catalytic surface was determined by Temperature-Programmed Reduction (TPR) in a Quantachrome ChemBET-300 instrument equipped with a thermal conductivity detector. Prior to analysis ca. $150 \mathrm{mg}$ was packed into a quartz cell, heated for $2 \mathrm{~h}$ at $200{ }^{\circ} \mathrm{C}$ under a stream of pure He and then cooled to room temperature. The experiments were performed between 30 and $900{ }^{\circ} \mathrm{C}$ in a flow of $5 \% \mathrm{H}_{2} / \mathrm{N}_{2}$, the temperature increasing linearly at a rate of $10^{\circ} \mathrm{C} \mathrm{min}-1$. The $\mathrm{O}_{2}$-chemisorption was conducted at $600{ }^{\circ} \mathrm{C}$ using a ChemBET analyzer (Quantachrome Instruments ${ }^{\circledR}$ ).

Micro-Raman spectra were collected using a Renishaw RL633 laser spectrometer. Measurements were performed by using a helium-neon laser $(632.8 \mathrm{~nm}$ and an effective power of $6 \mathrm{~mW}$ at the sample's surface) equipped with a CCD detector, $50 \times$ lens, and an experimental resolution of typically $1 \mu \mathrm{m}$ for 10 accumulations of $20 \mathrm{~s}$.

Textural characteristics of the matrices were determined from nitrogen adsorption isotherms, recorded at $-196{ }^{\circ} \mathrm{C}$ in an Autosorb IQ - Quantachrome Instrument. The samples (ca. $200 \mathrm{mg}$ ) were degassed for $2 \mathrm{~h}$ at $300{ }^{\circ} \mathrm{C}$ before analysis. Specific surface areas were determined by the Brunauer-Emmett-Teller equation (BET method) from adsorption isotherm generated in a relative pressure range $0.07<P / P_{\mathrm{o}}<0.3$. The total pore volume was calculated from the amount of $\mathrm{N}_{2}$ adsorbed at a relative pressure close to unity. The average pore diameter was determined by the Barrett-Joyner-Ha lenda $(\mathrm{BJH})$ method from the $\mathrm{N}_{2}$ desorption isotherms.

Small-angle X-ray scattering (SAXS) was carried out at the D11A-SAXS beam line at the LNLS synchrotron laboratory (Campinas, Brazil), using a Huber-423 three-circle diffractometer. The SAXS setup was equipped with a Si $\left(\begin{array}{lll}1 & 1 & 1\end{array}\right)$ monochromator, giving a horizontally focused X-ray beam. The incident X-ray wavelength $\lambda$ was $1.488 \mathrm{~nm}$ and the scattering angle $2 \theta$ was varied from $0^{\circ}$ to $10^{\circ}$.

Transmission electron microscope (TEM) images were taken with a Tecnai-G2-20 (FEI) electron microscope with an acceleration potential of $200 \mathrm{kV}$. The scanning electron microscopy (SEM) images were obtained using a JEOL field emission gun microscope JSM $6330 \mathrm{~F}$ operated at $5 \mathrm{kV}$. The samples were prepared by dropcasting an aqueous suspension containing the nanostructures over a silicon wafer, followed by drying under ambient conditions.

\subsection{Benzene, toluene and o-xylene oxidation}

The catalytic oxidation of benzene, toluene and 0 -xylene was investigated. The reactions were performed in a fixed-bed tubular quartz reactor under atmospheric pressure. The following conditions were chosen: $0.11 \mathrm{~g}$ of catalyst, inlet benzene ( $>99 \%$, Vetec) concentration $1.2 \mathrm{~g} \mathrm{~m}^{-3}$, toluene ( $>99 \%$, Vetec) concentration $0.7 \mathrm{~g} \mathrm{~m}^{-3}, o$-xylene $\left(>99 \%\right.$, Vetec) concentration $0.5 \mathrm{~g} \mathrm{~m}^{-3}$ in air and temperature range $150-400{ }^{\circ} \mathrm{C}$. The reaction data were collected after at least $2 \mathrm{~h}$ on stream at room temperature. The reaction products were determined by gas chromatography coupled to mass spectrometry (GC-MS). The reactant and product mixtures were analyzed with two in-line gas chromatographs equipped with FID and TCD detectors and an HP- 5 column. The catalytic activity was expressed as the percent conversion of benzene, toluene and 
$o$-xylene, respectively. The conversion of the compounds (benzene, toluene and $o$-xylene) was calculated as follows:

CBTXs $(\%)=\frac{[\text { BTXs }]_{\text {in }}-[\text { BTXs }]_{\text {out }}}{[\text { BTXs }]_{\text {in }}} \times 100 \%$

where CBTXs (\%) = percent BTX conversion; $[\mathrm{BTXs}]_{\text {in }}=$ input quantity and $[\text { BTXs }]_{\text {out }}=$ output quantity.

\section{Results and discussion}

We started our studies by focusing on well-defined $\mathrm{CeO}_{2}-\mathrm{MCM}-$ 41 materials obtained by the in situ incorporation of the cerium precursor into the mesoporous silica MCM-41 framework. During the synthesis, $\mathrm{SiO}_{2}$ is evenly distributed in the hexagonal structure of rod-like surfactant micelles of CTAB molecules (cetyltrimethylammonium bromide) to produce the MCM-41 structure $[25,26]$. In this case, $\mathrm{Ce}\left(\mathrm{NO}_{3}\right)_{3}$ (cerium precursor) was also added to the recipe in order to produce $\mathrm{CeO}_{2}$, together with $\mathrm{MCM}-41$, in the micellar solution of CTAB. It is expected that this approach would lead to catalysts with strong $\mathrm{CeO}_{2}-\mathrm{MCM}-41$ interactions. For the sake of comparison, we also prepared a $\mathrm{CeO}_{2}-\mathrm{SiO}_{2}$ catalyst by wet impregnation [27] of commercial $\mathrm{CeO}_{2}$ into $\mathrm{SiO}_{2}$ in order to investigate the influence of both methods on the structural features and catalytic properties towards the BTX oxidation. Fig. 1 shows the XRD patterns of the $\mathrm{CeO}_{2}-\mathrm{MCM}-41$ and $\mathrm{CeO}_{2}-\mathrm{SiO}_{2}$. Whereas the diffractogram of $\mathrm{CeO}_{2}-\mathrm{SiO}_{2}$ indicated four lines corresponding to the (1 111 ), (2 00 ), (2 20 ) and (3 111 ) crystal planes of cubic fluorite $\left(\mathrm{CeO}_{2}\right)$ [6], the $\mathrm{CeO}_{2}-\mathrm{MCM}-41$ did not present any well-defined peaks assigned to $\mathrm{CeO}_{2}$ phases. This observation suggests that the $\mathrm{CeO}_{2}$ is better dispersed on the in MCM- 41 framework relative to commercial silica and may exhibit an improved interaction with the mesoporous silica. The broad peak observed in $\mathrm{CeO}_{2}-\mathrm{MCM}-41$ diffractogram is due to amorphous $\mathrm{SiO}_{2}[28,29]$.

TPR experiments were performed in order to investigate the redox properties of the prepared catalysts. One broad reduction peak associated with the reduction of $\mathrm{Ce}^{4+}$ to $\mathrm{Ce}^{3+}$ in the bulk of the $\mathrm{CeO}_{2}$ was registered in the TPR profiles of both catalysts (Fig. 2) [30-32]. This peak was centered at 864 and $665{ }^{\circ} \mathrm{C}$ and for $\mathrm{CeO}_{2}-\mathrm{SiO}_{2}$ and $\mathrm{CeO}_{2}-\mathrm{MCM}-41$ catalysts, respectively, indicating the higher reducibility for the $\mathrm{CeO}_{2}-\mathrm{MCM}-41$ catalyst. This can be assigned to the high dispersion of $\mathrm{CeO}_{2}$ and interaction with the MCM-41 support [7,14,33]. In addition, the shift to a lower reduction temperature can also be ascribed to the higher surface $\mathrm{CeO}_{2}$ concentration and smaller crystallite size presented in this sample, which is consistent with XRD data [6,8,9,14].

$\mathrm{O}_{2}$-chemisorption measurements also support the XRD and TPR analysis and allowed us to estimate the total amount of oxygen

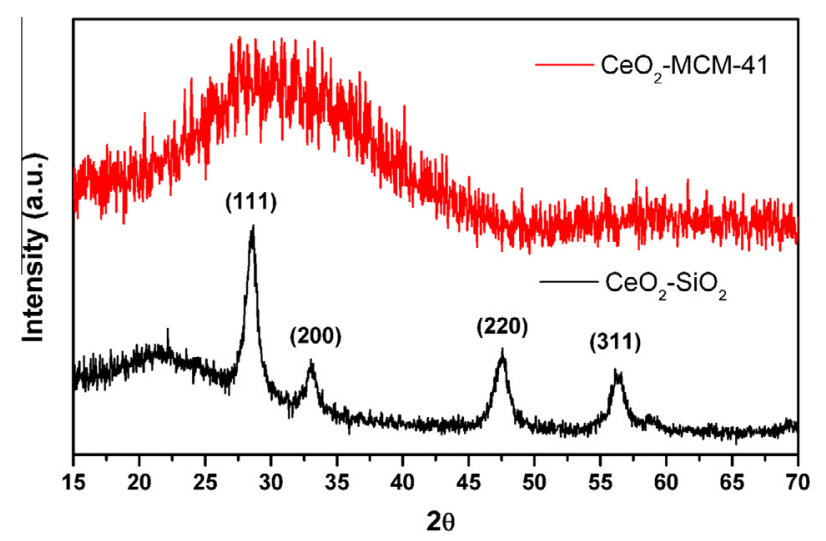

Fig. 1. XRD patterns of $\mathrm{CeO}_{2}-\mathrm{MCM}-41$ and $\mathrm{CeO}_{2}-\mathrm{SiO}_{2}$.

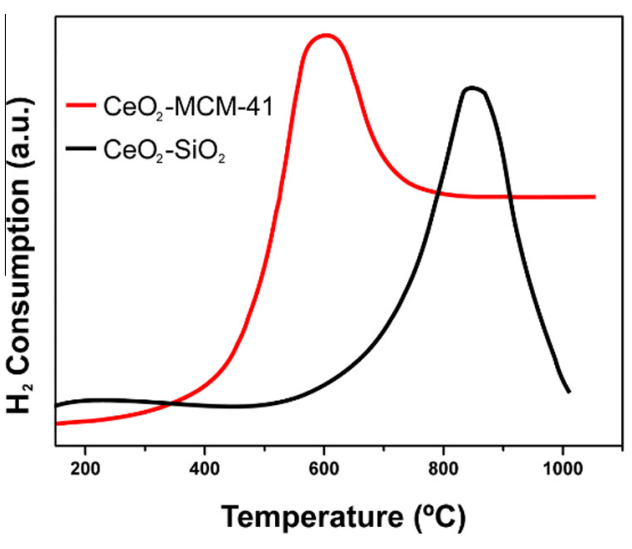

Fig. 2. TPR profiles of $\mathrm{CeO}_{2}-\mathrm{MCM}-41$ and $\mathrm{CeO}_{2}-\mathrm{SiO}_{2}$.

storage capacity (OSC) available in each catalyst, which is related to the number of oxygen vacancies in the samples. The $\mathrm{CeO}_{2}-\mathrm{MCM}-41$ catalyst exhibited a higher density of oxygen sites than $\mathrm{CeO}_{2}-\mathrm{SiO}_{2}$ catalyst $\left(5.15 \times 10^{3}\right.$ and $3.22 \times 10^{3} \mu \mathrm{mol} / \mathrm{m}^{2}$ for $\mathrm{CeO}_{2}-\mathrm{MCM}-41$ and $\mathrm{CeO}_{2}-\mathrm{SiO}_{2}$, respectively), indicating an interaction between $\mathrm{CeO}_{2}$ and the support as well as the higher oxygen vacancies concentration at the $\mathrm{CeO}_{2}-\mathrm{MCM}-41$ surface [34].

We also investigated the presence of oxygen vacancies in the $\mathrm{CeO}_{2}-\mathrm{SiO}_{2}$ and $\mathrm{CeO}_{2}-\mathrm{MCM}-41$ by Raman spectroscopy as shown in Fig. $3 \mathrm{~A}$ and $\mathrm{B}$. The Raman spectrum (Fig. 3A) of $\mathrm{CeO}_{2}-\mathrm{SiO}_{2}$ indicated a band centered at $466.4 \mathrm{~cm}^{-1}$, which is assigned to the $\mathrm{F}_{2 \mathrm{~g}}$ mode of the fluorite structure (symmetric stretching vibration of the oxygen atoms around $\mathrm{Ce}^{4+}$ ions) [6,35]. Interestingly, the $\mathrm{F}_{2 \mathrm{~g}}$ mode for the $\mathrm{CeO}_{2}-\mathrm{MCM}-41$ was broadened and shifted to $461.3 \mathrm{~cm}^{-1}$, which suggests the presence of defects on the $\mathrm{CeO}_{2}$ structure $[6,36,37]$. We also observed in the Raman spectra of $\mathrm{CeO}_{2}-\mathrm{MCM}-41$ two weak bands in the $540-620 \mathrm{~cm}^{-1}$ region corresponding to the non-degenerate $\mathrm{LO}$ modes of $\mathrm{CeO}_{2}$, assigned to the oxygen vacancies introduced into the ceria structure [6,36]. Therefore, our data indicate that $\mathrm{CeO}_{2}-\mathrm{MCM}-41$ presents increased the content of oxygen vacancies relative to the $\mathrm{CeO}_{2}-\mathrm{SiO}_{2}$ catalyst, which is in agreement with XRD and TPR results.

Surface areas and average pore sizes obtained by BET showed that specific surface area for the $\mathrm{CeO}_{2}-\mathrm{MCM}-41$ catalyst was much higher $\left(727 \mathrm{~m}^{2} / \mathrm{g}\right)$ than $\mathrm{CeO}_{2}-\mathrm{SiO}_{2}\left(153 \mathrm{~m}^{2} / \mathrm{g}\right)$. The $\mathrm{CeO}_{2}-\mathrm{MCM}-41$ catalysts also displayed a much smaller average $\mathrm{BJH}$ pore diameter

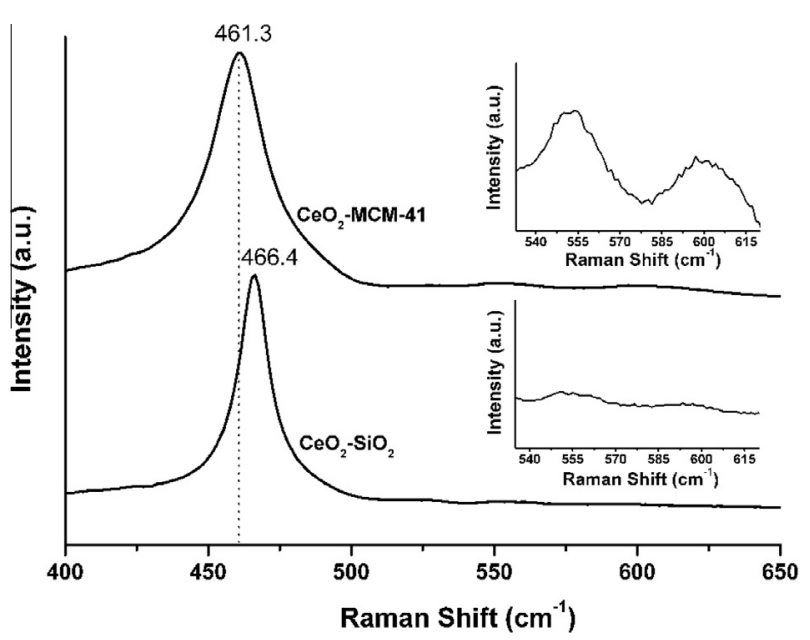

Fig. 3. Raman spectra of $\mathrm{CeO}_{2}-\mathrm{MCM}-41$ and $\mathrm{CeO}_{2}-\mathrm{SiO}_{2}$ catalysts. The insets present a zoom at the $530-620 \mathrm{~cm}^{-1}$ region. 
Table 1

Textural properties measured by $\mathrm{N}_{2}$-physisorption and $\mathrm{O}_{2}$-chemissortion for the $\mathrm{CeO}_{2}$-based catalysts.

\begin{tabular}{|c|c|c|c|c|}
\hline Catalyst & Density of oxygen sites $\left(\mu \mathrm{mol} / \mathrm{m}^{2}\right)$ & Surface area $\left(\mathrm{m}^{2} / \mathrm{g}\right)$ & Pore volume $\left(\mathrm{cm}^{3} / \mathrm{g}\right)$ & Pore diameter $(\AA)$ \\
\hline $1 \mathrm{wt} \% \mathrm{CeO}_{2}-\mathrm{MCM}-41$ & $2.99 \times 10^{3}$ & 832 & 1.0 & 2.0 \\
\hline $5 \mathrm{wt} \% \mathrm{CeO}_{2}-\mathrm{MCM}-41$ & $5.15 \times 10^{3}$ & 727 & 0.5 & 1.9 \\
\hline $10 \mathrm{wt} \% \mathrm{CeO}_{2}-\mathrm{MCM}-41$ & $3.89 \times 10^{3}$ & 169 & 0.8 & 2.5 \\
\hline $5 \mathrm{wt} \% \mathrm{CeO}_{2}-\mathrm{SiO}_{2}$ & $3.22 \times 10^{3}$ & 153 & 0.7 & 9.0 \\
\hline
\end{tabular}

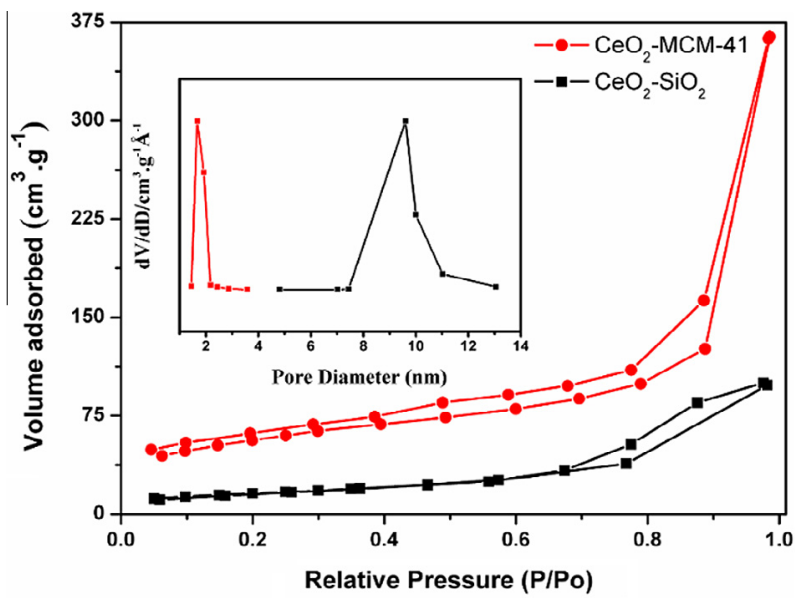

Fig. 4. $\mathrm{N}_{2}$-adsorption-desorption isotherms of $\mathrm{CeO}_{2}-\mathrm{MCM}-41$ and $\mathrm{CeO}_{2}-\mathrm{SiO}_{2}$ catalysts and pore size distribution curves (inset) generated by the $\mathrm{BJH}$ method from the $\mathrm{N}_{2}$ desorption isotherms.

$(1.9 \mathrm{~nm})$ relative to $\mathrm{CeO}_{2}-\mathrm{SiO}_{2}(9 \mathrm{~nm})$. These results are depicted in Table 1. The isotherm for $\mathrm{CeO}_{2}-\mathrm{SiO}_{2}$ catalyst (Fig. 4) corresponds to type IV (IUPAC classification), which is typical of mesoporous materials. The shape of the hysteresis loop type $\mathrm{H} 1$ appeared at relative pressures $P / P_{\mathrm{o}} \approx 0.9-1.0$ and could be related to the formation of textural mesoporosity [38]. The $\mathrm{CeO}_{2}-\mathrm{MCM}-41$ exhibited a type IV isotherm (Fig. 4) (IUPAC classification), with well-defined $\mathrm{H} 3$ loops that did not level off at relative pressures close to the saturation vapor pressure, as reported for aggregates of plate-like particles giving rise to slit-shaped pores. Thus, the high BET surface areas, type IV nitrogen adsorption-desorption isotherm, and narrow pore size distribution confirm the uniform mesoporosity and ordered structure of the $\mathrm{CeO}_{2}-\mathrm{MCM}-41$ material.

The ordered hexagonal structure of $\mathrm{CeO}_{2}-\mathrm{MCM}-41$ was further confirmed by HRTEM image (Fig. 5A), showing the hexagonal arrangement of uniform pores (inset of Fig. 5A). The HRTEM results also revels the absence of individual, small $\mathrm{CeO}_{2}$ aggregates, which agrees with XRD results and indicate that cerium could be successfully incorporated into the MCM-41 structure. On the other hand, the TEM image of $\mathrm{CeO}_{2}-\mathrm{SiO}_{2}$ catalyst (Fig. $5 \mathrm{~B}$ ) showed the presence of elongated and irregular particles of $\mathrm{CeO}_{2}$ and $\mathrm{SiO}_{2}$. Also, the mass-thickness contrast detected from the TEM image indicates that $\mathrm{SiO}_{2}$ and $\mathrm{CeO}_{2}$ particles were directly connected (Fig. $5 \mathrm{~B}$ ).

The structure of $\mathrm{CeO}_{2}-\mathrm{MCM}-41$ was also studied by SAXS. The synchrotron radiation small-angle pattern for the $\mathrm{CeO}_{2}-\mathrm{MCM}-41$ (Fig. 6) showed ( $\left.\begin{array}{lll}1 & 0 & 0\end{array}\right),\left(\begin{array}{lll}1 & 1 & 0\end{array}\right)$ and $\left(\begin{array}{lll}2 & 0 & 0\end{array}\right)$ reflections at $2 \theta=1.67^{\circ}$, $2.91^{\circ}$, and $3.33^{\circ}$, respectively. These reflections can be attributed to the 2-D hexagonal symmetry that is typical of the MCM-41 ordered hexagonal structure [25]. Therefore, these results indicated that in situ $\mathrm{CeO}_{2}$ generation during the synthesis of MCM41 did not prevent the formation of ordered mesoporous silica, which agree with HRTEM data.

The catalytic activity of the $\mathrm{CeO}_{2}-\mathrm{MCM}-41$ and $\mathrm{CeO}_{2}-\mathrm{SiO}_{2}$ samples was examined towards the oxidation of BTX compounds. We were interested in investigating how the catalytic performances
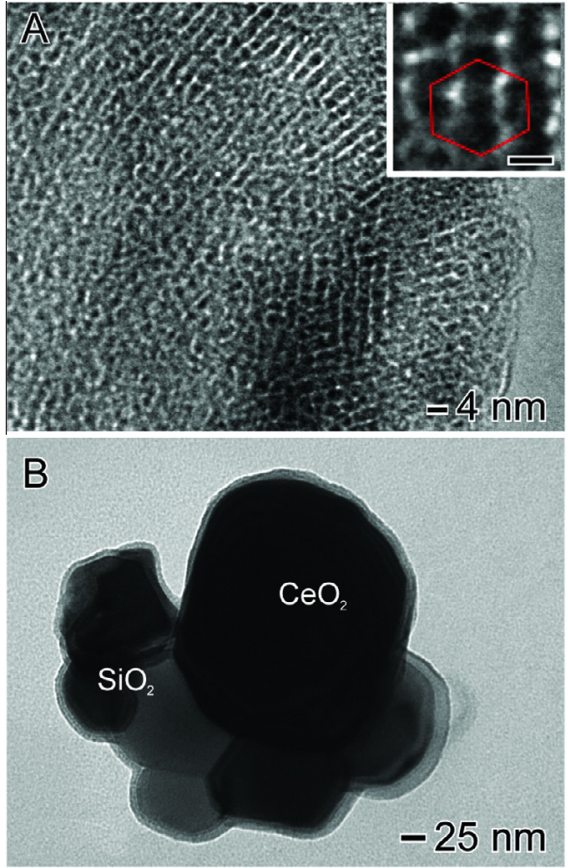

Fig. 5. HRTEM (A) and TEM (B) images of $\mathrm{CeO}_{2}-\mathrm{MCM}-41$ and $\mathrm{CeO}_{2}-\mathrm{SiO}_{2}$ catalysts, respectively. The scale bar the inset corresponds to $2 \mathrm{~nm}$.

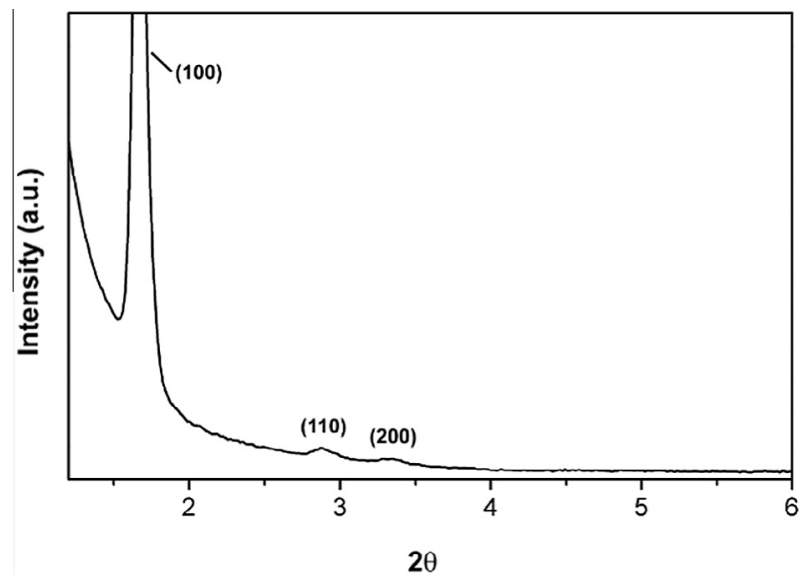

Fig. 6. $\mathrm{SAXS}$ pattern of $\mathrm{CeO}_{2}-\mathrm{MCM}-41$ catalyst.

of the $\mathrm{CeO}_{2}-\mathrm{MCM}-41$ and $\mathrm{CeO}_{2}-\mathrm{SiO}_{2}$ towards $\mathrm{BTX}$ oxidation were dependent upon their physicochemical properties. Fig. $7 \mathrm{~A}-\mathrm{C}$ depicts the conversion percentages for the oxidation of benzene (Fig. 7A), toluene (Fig. 7B), and 0 -xylene (Fig. 7C) as a function of reaction temperature employing $\mathrm{CeO}_{2}-\mathrm{MCM}-41$ and $\mathrm{CeO}_{2}-\mathrm{SiO}_{2}$ as catalysts. The inset in Fig. $6 \mathrm{~A}-\mathrm{C}$ shows the $\mathrm{TOF}_{\max }$ at maximum conversion of BTX. From Fig. 7A-C, it can be observed a significant difference regarding the activities of $\mathrm{CeO}_{2}-\mathrm{MCM}-41$ and $\mathrm{CeO}_{2}-\mathrm{SiO}_{2}$. While no appreciable conversion was detected for the 

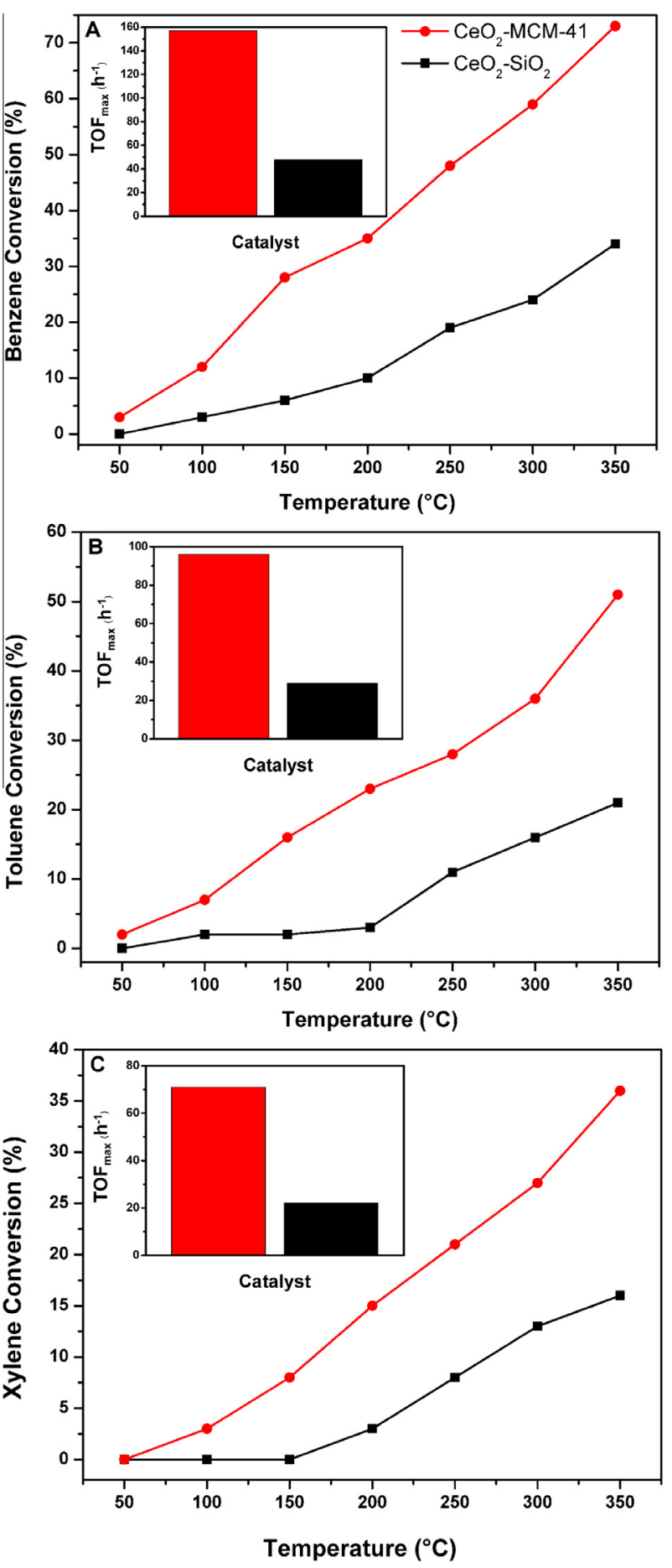

Fig. 7. BTX oxidation expressed as conversion \% as a function of temperature catalyzed by $\mathrm{CeO}_{2}-\mathrm{MCM}-41$ and $\mathrm{CeO}_{2}-\mathrm{SiO}_{2}$.

pure $\mathrm{SiO}_{2}$ support and $\mathrm{CeO}_{2}(<3 \%$, not shown in the Fig. 7), both $\mathrm{CeO}_{2}-\mathrm{MCM}-41$ and $\mathrm{CeO}_{2}-\mathrm{SiO}_{2}$ displayed high catalytic activities at relatively low temperatures, showing that the appropriate combination of oxides can provide higher activities relative to their individual counterparts. The oxidation of benzene, toluene and 0 xylene began to take place at above $60^{\circ} \mathrm{C}$. Only $\mathrm{H}_{2} \mathrm{O}$ and $\mathrm{CO}_{2}$ were detected as the oxidation products, and the BTX conversion increased with temperature for both catalysts. $\mathrm{CeO}_{2}-\mathrm{MCM}-41$ was notably more active than the $\mathrm{CeO}_{2}-\mathrm{SiO}_{2}$ at the higher temperatures. Specifically, 74\% and 33\% conversion for benzene, $53 \%$ and

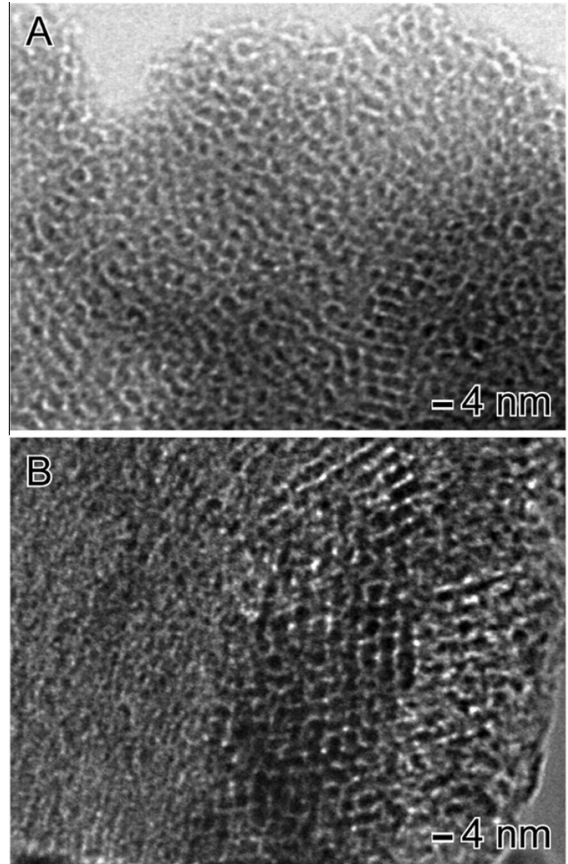

Fig. 8. HRTEM images of the $1 \mathrm{wt} \% \mathrm{CeO}_{2}-\mathrm{MCM}-41$ (A) and $10 \mathrm{wt} \% \mathrm{CeO}_{2}-\mathrm{MCM}-41$ (B) catalysts.

$19 \%$ conversion for toluene, and $37 \%$ and $15 \%$ conversion for 0 xylene were observed at $350{ }^{\circ} \mathrm{C}$ when $\mathrm{CeO}_{2}-\mathrm{MCM}-41$ and $\mathrm{CeO}_{2}-$ $\mathrm{SiO}_{2}$ were employed as catalysts, respectively. The TOF values followed the same trend corresponding to 157 and $48 \mathrm{~h}^{-1}$ for benzene, 96 and $29 \mathrm{~h}^{-1}$ for toluene and 72 and $23 \mathrm{~h}^{-1}$ for $o$-xylene using $\mathrm{CeO}_{2}-\mathrm{MCM}-41$ and $\mathrm{CeO}_{2}-\mathrm{SiO}_{2}$ as catalysts, respectively.

Assuming the same $\mathrm{CeO}_{2}$ content for both catalysts ( $5 \mathrm{wt} \%$ ), the higher activities for $\mathrm{CeO}_{2}-\mathrm{MCM}-41$ can be explained due to its higher specific surface area, stronger ceria-support interactions, and higher oxygen vacancy concentrations. In this case, the greater reducibility of $\mathrm{CeO}_{2}-\mathrm{MCM}-41$ was translated into higher oxidation activities $[6,8,14]$. The high amount of oxygen vacancies can result in an enhancement in the surface oxygen mobility [39]. In oxidation reactions, the catalyst is subjected to cycles of oxidation and reduction, in which both processes are affected by the oxygen mobility of the catalyst. It is a consensus that, when $\mathrm{CeO}_{2}$ based catalysts are involved, the oxidation of hydrocarbons occurs via the Mars-van Krevelen mechanism in which the solid oxidizes the substrate. Thus, the key steps are the supply of oxygen by the reducible oxide, the introduction of the oxygen species from the lattice oxide into the substrate molecule, and the reoxidation of the reduced solid by the oxygen-containing gaseous phase, which is the rate-determining step of the reaction $[2,9,40,41]$. Therefore, the results reported herein indicate that the methodology used to prepare $\mathrm{CeO}_{2}-\mathrm{MCM}-41$ led to the highest active catalyst for BTX oxidation.

We also investigated the influence of $\mathrm{CeO}_{2}$ content in the ordering of mesoporous structure and its catalytic performance. Fig. $8 \mathrm{~A}$ and $\mathrm{B}$ shows HRTEM images of 1 and $10 \mathrm{wt} \% \mathrm{CeO}_{2}-\mathrm{MCM}-$ 41. As expected, the increase of cerium content on the in situ $\mathrm{CeO}_{2}$ generation during the MCM-41 synthesis promoted partial disordering of mesoporous silica but it does not prevent the overall formation of the mesoporous structure (Fig. 8B). Both 1 and $5 \mathrm{wt} \%$ $\mathrm{CeO}_{2}-\mathrm{MCM}-41$ (Figs. 8A and 5A, respectively) displayed high uniformity, while the sample containing $10 \mathrm{wt} \% \mathrm{CeO}_{2}$ were less uniform. Indeed, this behavior was similar to other reported catalysts [25,26], in which transition metals have been incorporated 

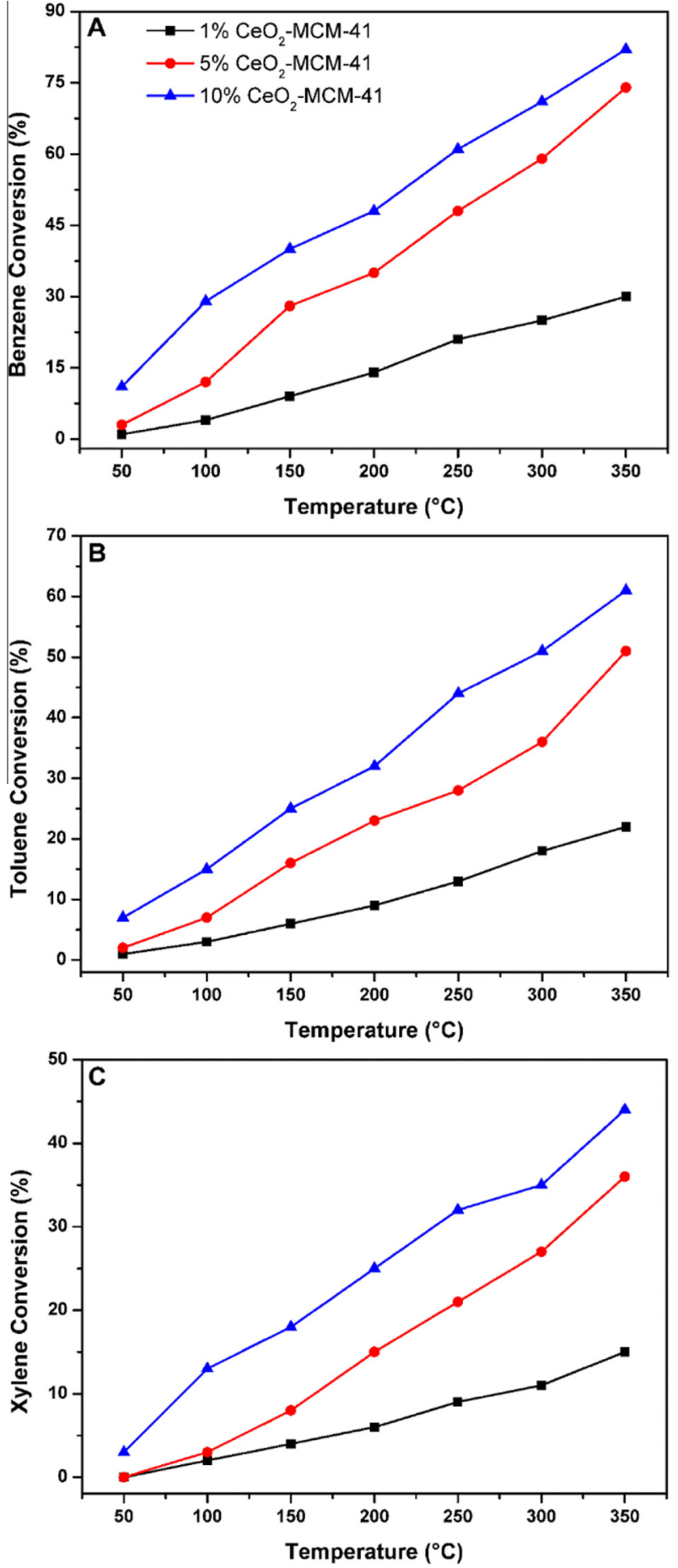

Fig. 9. BTX oxidation expressed as conversion $\%$ as a function of temperature catalyzed by 1,5 , and $10 \mathrm{wt} \% \mathrm{CeO}_{2}-\mathrm{MCM}-41$.

into the MCM-41 structure by mixing the dissolved metal precursor into the initial solution of TEOS, water, and CTAB. It is plausible that the increase of $\mathrm{CeO}_{2}$ content did not contribute to the formation of ordered surfactant aggregates, which are uniformly distributed in the hexagonal phase of rod-like surfactant micelles of alkyltrimethylammonium bromide surfactant.

BET and $\mathrm{O}_{2}$-chemissortion analyses are in agreement with the HRTEM results as depicted in Table 1. A slight decrease of surface area $\left(832-727 \mathrm{~m}^{2} / \mathrm{g}\right)$ and an increase in the density of oxygen sites $\left(2.99-5.15 \mu \mathrm{mol} / \mathrm{g}\right.$ ) were detected when the $\mathrm{CeO}_{2}$ content was
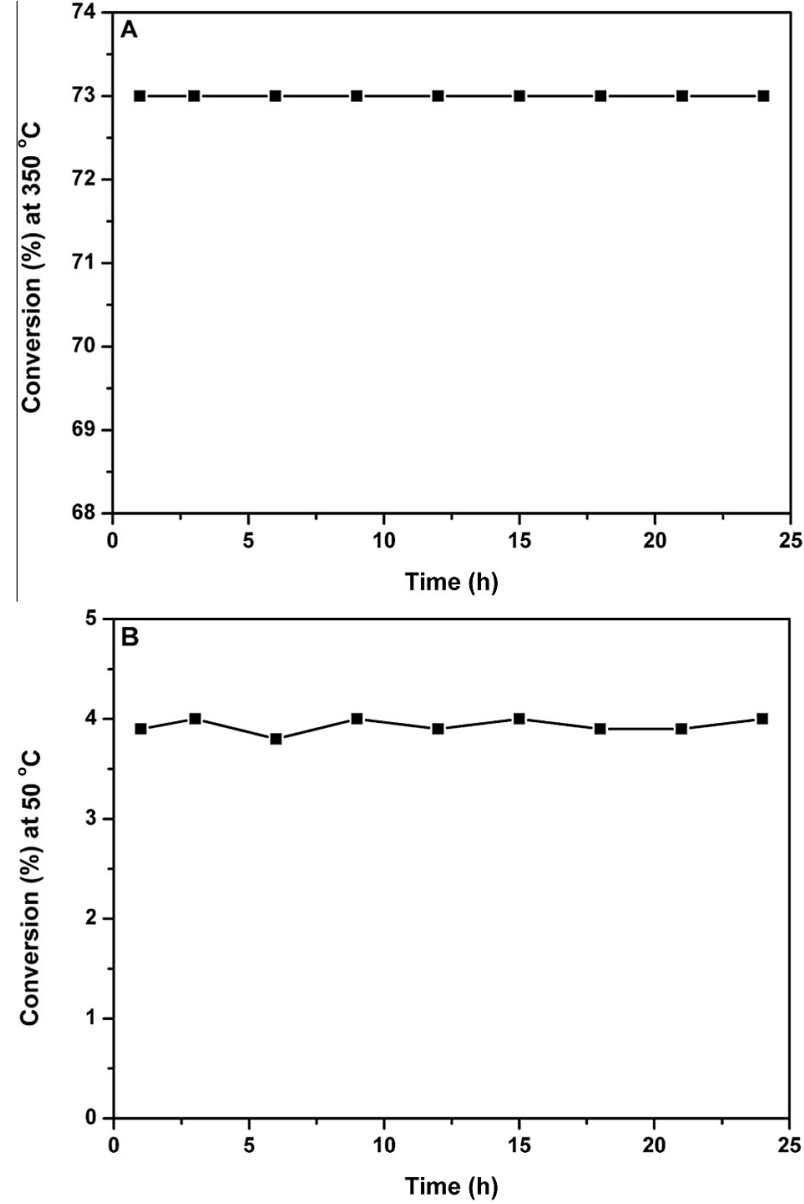

Fig. 10. Benzene conversion percentages as a function of time employing $5 \mathrm{wt} \%$ $\mathrm{CeO}_{2}-\mathrm{MCM}-41$ at $50{ }^{\circ} \mathrm{C}(\mathrm{A})$ and $350{ }^{\circ} \mathrm{C}(\mathrm{B})$ as the reaction temperature.

increased from 1 to $5 \mathrm{wt} \%$. Interestingly, the partial disordering of mesoporous structure observed for the $10 \mathrm{wt} \% \mathrm{CeO}_{2}-\mathrm{MCM}-41$ was also accompanied by significant changes in its textural properties, leading to surface areas and density of oxygen sites corresponding to $169 \mathrm{~m}^{2} / \mathrm{g}$ and $3.89 \times 10^{3} \mu \mathrm{mol} / \mathrm{m}^{2}$, respectively.

Fig. 9A-C depicts the conversion \% for the oxidation of benzene (Fig. 9A), toluene (Fig. 9B), and o-xylene (Fig. 9C) as a function of reaction temperature employing 1,5 , and $10 \mathrm{wt} \% \mathrm{CeO}_{2}-\mathrm{MCM}-41$ as catalysts, respectively. As expected, BTX conversion \% increased with the increase of $\mathrm{CeO}_{2}$ content, since $\mathrm{CeO}_{2}$ is the active phase of the catalysts. Although a significant increase of BTX conversion was observed when the $\mathrm{CeO}_{2}$ content varied from 1 to $5 \mathrm{wt} \%$, this behavior was not obtained for the $10 \mathrm{wt} \% \mathrm{CeO}_{2}-\mathrm{MCM}-41$ catalyst. The sample containing $10 \mathrm{wt} \% \mathrm{CeO}_{2}$ was only slightly better than $5 \mathrm{wt} \% \mathrm{CeO}_{2}-\mathrm{MCM}-41$ catalyst. Here, it is plausible that the disordering of mesoporous structure observed for the $10 \mathrm{wt} \% \mathrm{CeO}_{2}-$ MCM-41 catalyst led to a lower specific surface area, poorer interaction of ceria with the support, and lower concentration of oxygen vacancies in the $\mathrm{CeO}_{2}$ structure, thus leading to detrimental effects over their catalytic performances.

The catalytic stability towards the benzene oxidation was investigated as a function of time for the $5 \mathrm{wt} \% \mathrm{Ce} / \mathrm{MCM}-41$ catalyst as shown in Fig. 10. This material was chosen as it corresponds to the sample having the best uniformity, higher concentration of oxygen vacancies, and best textural properties. It can be observed that no significant loss of catalytic activity was detected even after $24 \mathrm{~h}$ when the reaction was performed both at 50 and $350^{\circ} \mathrm{C}$. This observation indicates that these materials may represent 
Table 2

Oxidation of benzene and toluene over $\mathrm{CeO}_{2} / \mathrm{MCM}-41$ catalysts and other catalysts reported in literature.

\begin{tabular}{|c|c|c|c|}
\hline Catalyst & $T_{\mathrm{BTX} 50}\left({ }^{\circ} \mathrm{C}\right)$ & Compound & Reference \\
\hline $\mathrm{CeO}_{2}-\mathrm{SiO}_{2}{ }^{\mathrm{a}}$ & $>350$ & BTX & This work \\
\hline $5 \% \mathrm{CeO}_{2}-\mathrm{MCM}-41^{\mathrm{a}}$ & 252 & Benzene & This work \\
\hline $5 \% \mathrm{CeO}_{2}-\mathrm{MCM}-41^{\mathrm{a}}$ & 348 & Toluene & This work \\
\hline $10 \% \mathrm{CeO}_{2}-\mathrm{MCM}-41^{\mathrm{a}}$ & 215 & Benzene & This work \\
\hline $10 \% \mathrm{CeO}_{2}-\mathrm{MCM}-41^{\mathrm{a}}$ & 290 & Toluene & This work \\
\hline $10 \% \mathrm{CeO}_{2}-\mathrm{MCM}-41^{\mathrm{a}}$ & $>350$ & $o$-Xylene & This work \\
\hline $\mathrm{CeO}_{2}^{\mathrm{b}}$ & $>500$ & Toluene & {$[42]$} \\
\hline $\mathrm{AuCeCP}$ & $>400$ & Toluene & [42] \\
\hline $\mathrm{AuCeDP}{ }^{\mathrm{b}}$ & 260 & Toluene & [42] \\
\hline $\mathrm{CeO}_{2} \mathrm{CM}^{\mathrm{c}}$ & 275 & Toluene & [43] \\
\hline $\mathrm{MnO}_{x}-\mathrm{CeO}_{2}{ }^{\mathrm{d}}$ & 270 & Toluene & [44] \\
\hline Co-UVM-7 $7^{\mathrm{e}}$ & 390 & Toluene & [45] \\
\hline $\mathrm{Au} / \mathrm{Co}-\mathrm{UVM}-7^{\mathrm{e}}$ & 255 & Toluene & [45] \\
\hline $\mathrm{Pd} / \mathrm{Co}_{3} \mathrm{O}_{4}(3 \mathrm{DL})^{\mathrm{f}}$ & 232 & o-Xylene & [46] \\
\hline $\mathrm{Pt} / \mathrm{AC} 800^{\mathrm{g}}$ & 131 & Benzene & [47] \\
\hline $\mathrm{Pt} / \mathrm{Al}_{2} \mathrm{O}_{3}{ }^{\mathrm{g}}$ & 170 & Benzene & [47] \\
\hline $\mathrm{V}_{2} \mathrm{O}_{5} / 4.37 \% \mathrm{Au} / \mathrm{TiO}_{2}{ }^{\mathrm{h}}$ & 200 & Benzene & [48] \\
\hline
\end{tabular}

${ }^{a}$ Gas mixture: 341, 199 and $142 \mathrm{ppm}$ benzene, toluene and $o$-xylene in air respectively; GHSV: $12,000 \mathrm{~h}^{-1}$.

b Gas mixture: $0.7 \%$ v/v toluene, 10 vol. $\% \mathrm{O}_{2}$ in helium; GHSV: $7.6 \times 10^{-3} \mathrm{~mol}$ $\left(\mathrm{h} \mathrm{g}_{\text {cat }}\right)^{-1}$.

c Gas mixture: $600 \mathrm{ppm}$ toluene, $20 \mathrm{vol} . \% \mathrm{O}_{2}$ in helium, flow rate of $50 \mathrm{~mL} \mathrm{~min}^{-1}$.

d Gas mixture: $200 \mathrm{ppm}$ benzene, 20 vol.\% $\mathrm{O}_{2}$ in helium; GHSV: $30 \mathrm{~mL}$ (h g gat $)^{-1}$.

e Gas mixture: $1000 \mathrm{vppm}$ in air; flow rate: $50 \mathrm{~mL} \mathrm{~min}^{-1}$.

f Gas mixture: $150 \mathrm{ppm}$ in air; flow rate: $100 \mathrm{~mL} \mathrm{~min}^{-1}$.

g Gas mixture: 1000 vppm in air; VHSV: $21,500 \mathrm{~h}^{-1}$.

h Gas mixture: 1206 vppm in air; VHSV: $21,500 \mathrm{~h}^{-1}$.

promising candidates for gas-phase catalytic applications. It important to note that the observed conversion at low temperature $\left(50^{\circ} \mathrm{C}\right)$ could not be assigned to an adsorption effect, as the chromatograms collected during the reaction at different temperatures clearly shows the substrate conversion and the concomitant appearing of $\mathrm{CO}_{2}$ as the reaction product (Fig. S1). In order to demonstrate that our reported approach for the synthesis of $\mathrm{CeO}_{2} / \mathrm{MCM}-41$ prepared by the in-situ incorporation of cerium precursor during the MCM-41 formation was effective for the production of optimized catalysts, their performance was also compared with those from a $\mathrm{CeO}_{2} / \mathrm{MCM}-41$ obtained by impregnation of cerium nitrate precursor over MCM-41 support as depicted in Fig. S2 under the same metal loading ( $5 \mathrm{wt} \%$ ). It can be observed that BTX conversion \% employing the $5 \mathrm{wt} \% \mathrm{CeO}_{2} / \mathrm{MCM}-41$ catalyst (Fig. S3) obtained by wet impregnation were significantly lower than the $5 \mathrm{wt} \% \mathrm{CeO}_{2} / \mathrm{MCM}-41$ catalyst prepared by in-situ incorporation of cerium precursor during the MCM-41 formation. Its performance was also compared with other catalysts reported in the literature as depicted in Table 2 [42-48]. It important to note that some catalytic results regarding the BTX oxidation are dependent on the employed operating conditions, including nature of the organic compound, reaction mixture composition, overall gas flow rate, and type of the reactor [22-24]. Moreover, most of reported ceria-based catalysts are employed combining other highly active phases such as noble metals or metal oxides (Pd, Pt, Co, Mn, $\mathrm{V}_{2} \mathrm{O}_{5}$, among others, Table 2). In this paper, silica (an inert phase) was studies as the support in order to focus on the contribution of $\mathrm{CeO}_{2}$. Regarding the $\mathrm{CeO}_{2}-\mathrm{MCM}-41$ catalysts, which presented the highest activity, the $T_{50}$ (temperature for the $50 \%$ organic compound conversion) was higher relative to other reported catalysts. It is interesting to note that the $T_{\text {Benzene50 }}$ of $10 \mathrm{wt} \% \mathrm{CeO}_{2}-\mathrm{MCM}-41$ was higher than Pt-based catalysts and comparable to the value of the $\mathrm{V}_{2} \mathrm{O}_{5} / 4.37 \% \mathrm{Au} / \mathrm{TiO}_{2}$. Besides, the $T_{\text {Toluene50 }}$ corresponded to $348{ }^{\circ} \mathrm{C}$ over $5 \% \mathrm{CeO}_{2}-\mathrm{MCM}-41$ and $300{ }^{\circ} \mathrm{C}$ over $10 \% \mathrm{CeO}_{2}-\mathrm{MCM}-41$ whereas this value was $390^{\circ} \mathrm{C}$ over Co-UVM-7. These observations indicate that the $\mathrm{CeO}_{2}-\mathrm{MCM}-41$ catalytic systems can be considered as efficient catalysts for the BTX oxidation. We believe the approach described herein not only enables the synthesis of $\mathrm{CeO}_{2}$ catalysts in less steps relative to conventional wet impregnation, but also lead to materials with improved activities towards the BTX oxidation.

\section{Conclusion}

The $\mathrm{CeO}_{2}-\mathrm{MCM}-41$ catalyst prepared by the in situ impregnation of a cerium precursor during the MCM-41 synthesis presented improved catalytic performance relative the $\mathrm{CeO}_{2}-\mathrm{SiO}_{2}$ catalyst prepared by the conventional wet impregnation. The higher catalytic activity was a result of its higher specific surface area, improved interaction between ceria and the support, facilitated $\mathrm{Ce}^{4+} / \mathrm{Ce}^{3+}$ redox process, and higher concentration of oxygen vacancies at the $\mathrm{CeO}_{2}$ surface, which benefits the migration of oxygen species across its structure and thus oxidation activity. Indeed, our results demonstrated that the method of preparation strongly affects the dispersion/incorporation of the $\mathrm{CeO}_{2}$ into $\mathrm{SiO}_{2}$, which can be put to work to yield improved catalytic performances.

\section{Acknowledgements}

Financial support from CNPq, CAPES, FAPESP, and FAPEMIG (Brazil) is gratefully acknowledged.

\section{Appendix A. Supplementary data}

Supplementary data associated with this article can be found, in the online version, at http://dx.doi.org/10.1016/j.cej.2015.10.097.

\section{References}

[1] J.Y.Z. Chiou, J.-Y. Siang, S.-Y. Yang, K.-F. Ho, C.-L. Lee, C.-T. Yeh, et al., Pathways of ethanol steam reforming over ceria-supported catalysts, Int. J. Hydrogen Energy 37 (2012) 13667-13673.

[2] N. Guillén-Hurtado, A. García-García, A. Bueno-López, Isotopic study of ceriacatalyzed soot oxidation in the presence of $\mathrm{NO}_{x}$, J. Catal. 299 (2013) 181-187.

[3] M. Cargnello, V.V.T. Doan-Nguyen, T.R. Gordon, R.E. Diaz, E.A. Stach, R.J. Gorte, et al., Control of metal nanocrystal size reveals metal-support interface role for ceria catalysts, Science 341 (2013) 771-773.

[4] Y. Wang, F. Wang, Q. Song, Q. Xin, S. Xu, J. Xu, Heterogeneous ceria catalyst with water-tolerant lewis acidic sites for one-pot synthesis of 1,3-diols via Prins condensation and hydrolysis reactions, J. Am. Chem. Soc. 135 (2013) $1506-1515$.

[5] T.X.T. Sayle, M. Cantoni, U.M. Bhatta, S.C. Parker, S.R. Hall, G. Möbus, et al., Strain and architecture-tuned reactivity in ceria nanostructures; enhanced catalytic oxidation of $\mathrm{CO}$ to $\mathrm{CO}_{2}$, Chem. Mater. 24 (2012) 1811-1821.

[6] A.G.M. Silva, T.S. Rodrigues, A. Dias, H.V. Fajardo, R.F. Goncalves, M. Godinho, et al., $\mathrm{Ce}_{1-\gamma} \mathrm{Sm}_{x} \mathrm{O}_{19_{-} \delta}$ nanoparticles obtained by microwave-assisted hydrothermal processing: an efficient application for catalytic oxidation of a-bisabolol, Catal. Sci. Technol. 4 (2014) 814-821.

[7] M. Nolan, S.C. Parker, G.W. Watson, The electronic structure of oxygen vacancy defects at the low index surfaces of ceria, Surf. Sci. 595 (2005) 223-232.

[8] J. Vecchietti, A. Bonivardi, W. Xu, D. Stacchiola, J.J. Delgado, M. Calatayud, et al., Understanding the role of oxygen vacancies in the water gas shift reaction on ceria-supported platinum catalysts, ACS Catal. 4 (2014) 2088-2096.

[9] J.M. López, A.L. Gilbank, T. García, B. Solsona, S. Agouram, L. TorrenteMurciano, The prevalence of surface oxygen vacancies over the mobility of bulk oxygen in nanostructured ceria for the total toluene oxidation, Appl. Catal., B 174-175 (2015) 403-412.

[10] R. Zhang, L. Guo, C. Chen, J. Chen, A. Chen, X. Zhao, et al., The role of Mn doping in $\mathrm{CeO}_{2}$ for catalytic synthesis of aliphatic carbamate from $\mathrm{CO}_{2}$, Catal. Sci. Technol. (2015).

[11] J.S. Moura, J. da S.L. Fonseca, N. Bion, F. Epron, T. de F. Silva, C.G. Maciel, et al., Effect of lanthanum on the properties of copper, cerium and zirconium catalysts for preferential oxidation of carbon monoxide, Catal. Today 228 (2014) 40-50.

[12] M. Hatanaka, N. Takahashi, T. Tanabe, Y. Nagai, K. Dohmae, Y. Aoki, et al., Ideal Pt loading for a $\mathrm{Pt} / \mathrm{CeO}_{2}$-based catalyst stabilized by a Pt-O-Ce bond, Appl, Catal., B 99 (2010) 336-342.

[13] J.L. Ayastuy, A. Iglesias-González, M.A. Gutiérrez-Ortiz, Synthesis and characterization of low amount tin-doped ceria $\left(\mathrm{Ce}_{X} \mathrm{Sn}_{1-X} \mathrm{O}_{2-\delta}\right)$ for catalytic CO oxidation, Chem. Eng. J. 244 (2014) 372-381.

[14] O.H. Laguna, A. Pérez, M.A. Centeno, J.A. Odriozola, Synergy between gold and oxygen vacancies in gold supported on $\mathrm{Zr}$-doped ceria catalysts for the $\mathrm{CO}$ oxidation, Appl. Catal., B 176-177 (2015) 385-395. 
[15] A.I. Carrillo, E. Serrano, J.C. Serrano-Ruiz, R. Luque, J. Garcia-Martinez, Helical Al- and Ce-MCM-41 materials as novel catalyst for acid and redox processes, Appl. Catal., A 435-436 (2012) 1-9.

[16] A.M. Akondi, R. Trivedi, B. Sreedhar, M.L. Kantam, S. Bhargava, Ceriumcontaining MCM-41 catalyst for selective oxidative arene crossdehydrogenative coupling reactions, Catal. Today 198 (2012) 35-44.

[17] S. Gnanam, V. Rajendran, Synthesis of $\mathrm{CeO}_{2}$ or $\alpha-\mathrm{Mn}_{2} \mathrm{O}_{3}$ nanoparticles via solgel process and their optical properties, J. Sol-Gel Sci. Technol. 58 (2011) 6269.

[18] C. Tyrsted, K.M. Ørnsbjerg Jensen, E.D. Bøjesen, N. Lock, M. Christensen, S.J.L. Billinge, et al., Understanding the formation and evolution of ceria nanoparticles under hydrothermal conditions, Angew. Chem. 124 (2012) 9164-9167.

[19] R. Inguanta, S. Piazza, C. Sunseri, Template electrosynthesis of $\mathrm{CeO}_{2}$ nanotubes, Nanotechnology 18 (2007) 485605.

[20] A. Gurbani, J.L. Ayastuy, M.P. González-Marcos, J.E. Herrero, J.M. Guil, M.A. Gutiérrez-Ortiz, Comparative study of $\mathrm{CuO}-\mathrm{CeO}_{2}$ catalysts prepared by wet impregnation and deposition-precipitation, Int. J. Hydrogen Energy 34 (2009) 547-553.

[21] I.W.C.E. Arends, R.A. Sheldon, Activities and stabilities of heterogeneous catalysts in selective liquid phase oxidations: recent developments, Appl. Catal., A 212 (2001) 175-187.

[22] W.B. Li, J.X. Wang, H. Gong, Catalytic combustion of VOCs on non-noble metal catalysts, Catal. Today 148 (2009) 81-87.

[23] F.I. Khan, A.Kr. Ghoshal, Removal of volatile organic compounds from polluted air, J. Loss Prev. Process Ind. 13 (2000) 527-545.

[24] L.F. Liotta, Catalytic oxidation of volatile organic compounds on supported noble metals, Appl. Catal., B 100 (2010) 403-412.

[25] A.G.M. da Silva, H.V. Fajardo, R. Balzer, L.F.D. Probst, A.S.P. Lovón, J.J. LovónQuintana, et al., Versatile and efficient catalysts for energy and environmental processes: mesoporous silica containing $\mathrm{Au}, \mathrm{Pd}$ and $\mathrm{Au}-\mathrm{Pd}$, J. Power Sources 285 (2015) 460-468.

[26] P.A. Robles-Dutenhefner, K.A. da Silva Rocha, E.M.B. Sousa, E.V. Gusevskaya, Cobalt-catalyzed oxidation of terpenes: Co-MCM-41 as an efficient shapeselective heterogeneous catalyst for aerobic oxidation of isolongifolene under solvent-free conditions, J. Catal. 265 (2009) 72-79.

[27] S.P. Jiang, A review of wet impregnation-an alternative method for the fabrication of high performance and nano-structured electrodes of solid oxide fuel cells, Mater. Sci. Eng., A 418 (2006) 199-210.

[28] M.G. Speziali, A.G.M. da Silva, D.M.V. de Miranda, A.L. Monteiro, P.A. RoblesDutenhefner, Air stable ligandless heterogeneous catalyst systems based on Pd and Au supported in $\mathrm{SiO}_{2}$ and MCM-41 for Suzuki-Miyaura cross-coupling in aqueous medium, Appl. Catal., A 462-463 (2013) 39-45.

[29] A.M. da Silva, P. Robles-Dutenhefner, A. Dias, H. Fajardo, A.P. Lovón, J. LovónQuintana, et al., Gold, palladium and gold-palladium supported on silica catalysts prepared by sol-gel method: synthesis, characterization and catalytic behavior in the ethanol steam reforming, J. Sol-Gel Sci. Technol. 67 (2013) 273-281.

[30] K. Krishna, A. Bueno-López, M. Makkee, J.A. Moulijn, Potential rare earth modified $\mathrm{CeO}_{2}$ catalysts for soot oxidation: I. Characterisation and catalytic activity with $\mathrm{O}_{2}$, Appl. Catal., B 75 (2007) 189-200.

[31] N. Sutradhar, A. Sinhamahapatra, S. Pahari, M. Jayachandran, B. Subramanian, H.C. Bajaj, et al., Facile low-temperature synthesis of ceria and samarium- doped ceria nanoparticles and catalytic allylic oxidation of cyclohexene, J. Phys. Chem. C 115 (2011) 7628-7637.

[32] S. Mandal, K.K. Bando, C. Santra, S. Maity, O.O. James, D. Mehta, et al., Sm- $-\mathrm{CeO}_{2}$ supported gold nanoparticle catalyst for benzyl alcohol oxidation using molecular $\mathrm{O}_{2}$, Appl. Catal., A 452 (2013) 94-104.

[33] L. Żivković, V. Lair, O. Lupan, A. Ringuedé, Effect of samarium addition and annealing on the properties of electrodeposited ceria thin films, Thin Solid Films 519 (2011) 3538-3543.

[34] R. Balzer, L.F.D. Probst, V. Drago, W.H. Schreiner, H.V. Fajardo, Catalytic oxidation of volatile organic compounds (n-hexane, benzene, toluene, oxylene) promoted by cobalt catalysts supported on $\mathrm{Al}_{2} \mathrm{O}_{3}-\mathrm{CeO}_{2}$, Braz. J. Chem. Eng. 31 (2014) 757-769.

[35] B.M. Reddy, A. Khan, P. Lakshmanan, M. Aouine, S. Loridant, J.-C. Volta, Structural characterization of nanosized $\mathrm{CeO}_{2}-\mathrm{SiO}_{2}, \mathrm{CeO}_{2}-\mathrm{TiO}_{2}$, and $\mathrm{CeO}_{2}-\mathrm{ZrO}_{2}$ catalysts by XRD, Raman, and HREM techniques, J. Phys. Chem. B 109 (2005) 3355-3363.

[36] B.M. Reddy, A. Khan, Y. Yamada, T. Kobayashi, S. Loridant, J.-C. Volta, Surface characterization of $\mathrm{CeO}_{2} / \mathrm{SiO}_{2}$ and $\mathrm{V}_{2} \mathrm{O}_{5} / \mathrm{CeO}_{2} / \mathrm{SiO}_{2}$ catalysts by Raman, XPS and other techniques, J. Phys. Chem. B 106 (2002) 10964-10972.

[37] B.M. Reddy, P. Lakshmanan, A. Khan, Investigation of surface structures of dispersed $\mathrm{V}_{2} \mathrm{O}_{5}$ on $\mathrm{CeO}_{2}-\mathrm{SiO}_{2}, \mathrm{CeO}_{2}-\mathrm{TiO}_{2}$, and $\mathrm{CeO}_{2}-\mathrm{ZrO}_{2}$ mixed oxides by XRD, Raman, and XPS techniques, J. Phys. Chem. B 108 (2004) 16855-16863.

[38] A. Corma, From microporous to mesoporous molecular sieve materials and their use in catalysis, Chem. Rev. 97 (1997) 2373-2420.

[39] S. Todorova, A. Naydenov, H. Kolev, K. Tenchev, G. Ivanov, G. Kadinov, Effect of $\mathrm{Co}$ and $\mathrm{Ce}$ on silica supported manganese catalysts in the reactions of complete oxidation of $n$-hexane and ethyl acetate, J. Mater. Sci. 46 (2011) 7152-7159.

[40] C. Fang, D. Zhang, L. Shi, R. Gao, H. Li, L. Ye, et al., Highly dispersed $\mathrm{CeO}_{2}$ on carbon nanotubes for selective catalytic reduction of $\mathrm{NO}$ with $\mathrm{NH}_{3}$, Catal. Sci. Technol. 3 (2013) 803-811.

[41] S. Todorova, G. Kadinov, K. Tenchev, A. Caballero, J.P. Holgado, R. Pereñíguez, $\mathrm{Co}_{3} \mathrm{O}_{4}+\mathrm{CeO}_{2} / \mathrm{SiO}_{2}$ catalysts for $n$-hexane and $\mathrm{CO}$ oxidation, Catal. Lett. 129 (2009) 149-155.

[42] S. Scirè, S. Minicò, C. Crisafulli, C. Satriano, A. Pistone, Catalytic combustion of volatile organic compounds on gold/cerium oxide catalysts, Appl. Catal., B 40 (2003) 43-49.

[43] D. Delimaris, T. Ioannides, VOC oxidation over $\mathrm{MnO}_{x}-\mathrm{CeO}_{2}$ catalysts prepared by a combustion method, Appl. Catal., B 84 (2008) 303-312.

[44] X. Tang, Y. Xu, W. Shen, Promoting effect of copper on the catalytic activity of $\mathrm{MnO}_{x}-\mathrm{CeO}_{2}$ mixed oxide for complete oxidation of benzene, Chem. Eng. J. 144 (2008) 175-180.

[45] B. Solsona, M. Pérez-Cabero, I. Vázquez, A. Dejoz, T. García, J. ÁlvarezRodríguez, et al., Total oxidation of VOCs on Au nanoparticles anchored on Co doped mesoporous UVM-7 silica, Chem. Eng. J. 187 (2012) 391-400.

[46] Y. Wang, C. Zhang, F. Liu, H. He, Well-dispersed palladium supported on ordered mesoporous $\mathrm{Co}_{3} \mathrm{O}_{4}$ for catalytic oxidation of 0 -xylene, Appl. Catal., B 142-143 (2013) 72-79.

[47] J.C.-S. Wu, Z.-A. Lin, F.-M. Tsai, J.-W. Pan, Low-temperature complete oxidation of BTX on Pt/activated carbon catalysts, Catal. Today 63 (2000) 419-426.

[48] V. Idakiev, L. Ilieva, D. Andreeva, J.L. Blin, L. Gigot, B.L. Su, Complete benzene oxidation over gold-vanadia catalysts supported on nanostructured mesoporous titania and zirconia, Appl. Catal., A 243 (2003) 25-39. 